\title{
Analysis of Emission Characteristics and Emission Factors of Carbon Monoxide and Nitrogen Oxide Emitted from Wood Pellet Combustion in Industrial Wood Pellet Boilers Supplied According to the Subsidy Program of Korea Forest Service ${ }^{1}$ 通
}

\author{
Sea Byul Kang ${ }^{2} \cdot$ Kyu Sung Choi ${ }^{2} \cdot$ Hyun Hee Lee ${ }^{2} \cdot$ Gyu-Seong Han $\mathbb{D}^{3, \dagger}$
}

\begin{abstract}
Korea Forest Service has supplied 76 industrial wood pellet boilers from 2011 to 2015 through subsidy programs. Since carbon monoxide $(\mathrm{CO})$ and nitrogen oxides $\left(\mathrm{NO}_{\mathrm{x}}\right)$ generated during boiler combustion are substances that lead to death in the case of acute poisoning, it is very important to reduce emissions. Therefore, the $\mathrm{CO}$ and $\mathrm{NO}_{\mathrm{x}}$ emission values of 63 boilers excluding the hot air blower and some boilers initially supplied were analyzed. The emission factor was also calculated from the measured exhaust gas concentration (based on exhaust gas $\mathrm{O}_{2}$ concentration of $12 \%)$. The average value of CO emitted from industrial wood pellet boilers was $49 \mathrm{ppm}$ and it was confirmed that the CO concentration was decreasing as the years passed. The emission factor of CO was $0.73 \mathrm{~g} / \mathrm{kg}$. The average value of $\mathrm{NO}_{\mathrm{x}}$ emitted from industrial wood pellet boilers was $67 \mathrm{ppm}$ and the emission factor of $\mathrm{NO}_{\mathrm{x}}$ was $1.63 \mathrm{~g} / \mathrm{kg}$. Unlike $\mathrm{CO}$, there was no tendency to decrease according to the installation year. Both $\mathrm{CO}$ and $\mathrm{NO}_{\mathrm{x}}$ measurements met the limits of the Ministry of Environment. These $\mathrm{NO}_{\mathrm{x}}$ emission factors were compared with the $\mathrm{NO}_{\mathrm{x}}$ emission factors produced by certified low $\mathrm{NO}_{\mathrm{x}}$ burners. The $\mathrm{NO}_{\mathrm{x}}$ emission factor of industrial wood pellet boilers was about 1.9 times that of certified low $\mathrm{NO}_{\mathrm{x}}$ LNG combustors and about 0.92 times that of coal combustion.
\end{abstract}

Keywords: emission, carbon monoxide, nitrogen oxide, industrial wood pellet boiler

\section{INTRODUCTION}

Korea Forest Service (KFS) have subsided the distribution and installation of industrial wood pellet boilers from 2011 to 2015 by expanding wood pellet consumption. This has helped step up the domestic industrial wood pellet boiler technology as it resulted in installing 76 industrial wood pellet combustors during the same period. For the effective distribution and management of the industrial wood pellet boilers, KFS established the Industrial Wood Pellet Boiler Subsidy Standards (KFS, 2015) and the Construction Inspection

\footnotetext{
${ }^{1}$ Date Received August 14, 2018, Date Accepted September 11, 2018

${ }^{2}$ Energy Network Laboratory, Korea Institute of Energy Research, 152 Gajung-ro, Yuseong-Gu, Daejeon 34129, Republic of Korea

${ }^{3}$ Department of Wood and Paper Science, College of Agriculture, Life \& Environments Sciences, Chungbuk National University, Cheongju 28644, Republic of Korea

† Corresponding author: Gyu-Seong Han (e-mail: wood@chungbuk.ac.kr, ORCID: 0000-0003-3835-2063)
} 
Sea Byul Kang $\cdot$ Kyu Sung Choi $\cdot$ Hyun Hee Lee $\cdot$ Gyu-Seong Han

Standards for Industrial Wood Pellet Boilers (KFS, 2013). The target industrial wood pellet boilers were steam boilers in $0-5$ to 7.0 ton/h or hot water boilers and heaters in $230 \mathrm{~kW}$ or over. 63 of them were steam boilers, 7 of them were hot water boilers, and 6 of them were hot wind heaters. To receive subsidies for wood pellet boilers, the following conditions need to be met: 1) The boiler heat efficiency at over $85 \%$ based on the lower heating value; 2) the preparation of safety device like a backfire prevention device; and 3) the $\mathrm{CO}$ emissions, one of the air pollution substances, being below 200 ppm.

In Korea, air pollutants related to the combustion of wood pellets are regulated by the Clean Air Conservation Act (ME, 2017). The target missions generated by combustion facilities at or over a certain size according to the Clean Air Conservation Act are 1) among wood pellet manufacturing facilities (screening, drying and heating facilities, crushing and grinding facilities, compression and molding facilities), facilities in which fuel consumption is over $30 \mathrm{~kg}$ per hour, the capacity is over $3 \mathrm{~m}^{2}$ or more, or power capacity is $2.25 \mathrm{~kW}$ (15 kW for crushing and grinding facilities) or more and 2) among the facilities that use wood pellets, those in which the usage of fuel products is over $200 \mathrm{~kg}$ per hour (excluding those that use other fuels together with wood pellets) (ME, 2017).

The allowable criteria of the air pollutants applied since 2015 shows that the CO concentration in a facility that uses wood pellets should be at or below 200 ppm ( $12 \%$ of the actually measured oxygen concentration). Nitrogen oxide $\left(\mathrm{NO}_{\mathrm{x}}, \mathrm{NO}_{2}\right)$ should be at or below 100 ppm for drying and heating facilities of wood pellet manufacturing facilities, or at or below $150 \mathrm{ppm}$ for facilities that use wood pellets (12\% of the actually measured oxygen concentration). Fine dust should be at or below $50 \mathrm{mg} / \mathrm{Sm}^{3}$ for both wood pellet manufacturing facilities or those which use wood pellets (12\% of the actually measured oxygen concentration)
(ME, 2017). With very low sulfur oxide and heavy metal content in wood pellets due to the fuel characteristics, there is no allowable criteria for those substances.

At the Parliamentary Inspection of the Administration in 2017, it was argued that the wood pellet combustion test showed that it produced 20 times as much nitrogen oxide, which generates ultrafine dust, as coal briquette, and there was a social controversy as the contents were quoted and reported without verification. (Kim, 2017). This is because while there has been research on the manufacturing characteristics of wood pellets in Korea (Kim et al., 2015; Yang et al., 2017), there has been little on air pollutants during wood pellet combustion.

The study aimed to measure air pollutants generated during the combustion of wood pellet boilers subsided by KFS, through which it verified whether industrial wood pellet boilers conformed the allowable criteria of air pollutants by the Ministry of Environment. Furthermore, based on the emissions of air pollutants, it determined the emission factors of industrial wood pellets boilers, which was compared to the $\mathrm{NO}_{\mathrm{x}}$ emitted from low- $\mathrm{NO}_{\mathrm{x}}$ certified burner.

\section{MATERIALS and METHODS}

\subsection{Survey target}

There were 9 KFS subsidized industrial wood pellet boilers (steam boilers, hot water boilers, hot wind heaters) in 2011, 27 in 2012, 21 in 2013, 10 in 2014, and 9 in 2015. 63 boilers excluding hot wind heaters and some distributed earlier were the target for this study. Shown in Fig. 1 is the current installation conditions by region. Over $50 \%$ of the subsidized industrial wood pellet boilers were installed in Gyeonggi-do and Gyeongsangnam-do. It is believed that this is because there are many companies in industrial regions where there is high demand on industrial boilers. It also shows 
Analysis of Emission Characteristics and Emission Factors of Carbon Monoxide and Nitrogen Oxide Emitted from Wood Pellet Combustion in Industrial Wood Pellet Boilers Supplied According to the Subsidy Program of Korea Forest Service

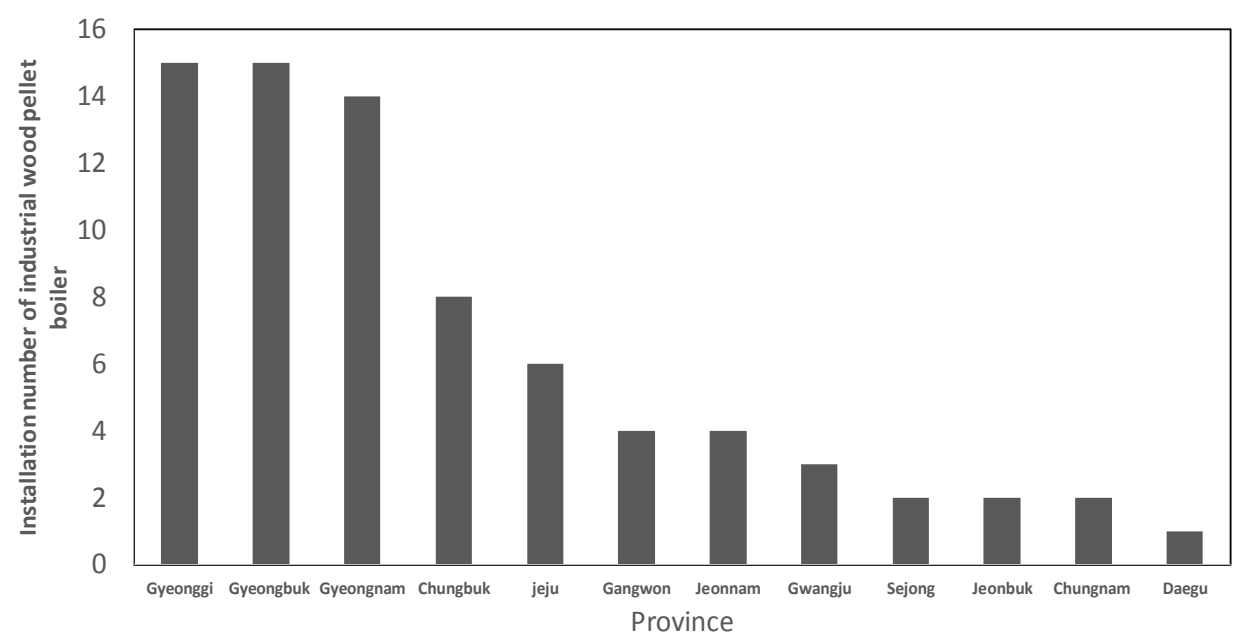

Fig. 1. Number of industrial wood pellet boiler with subsidy with respect to installed province.

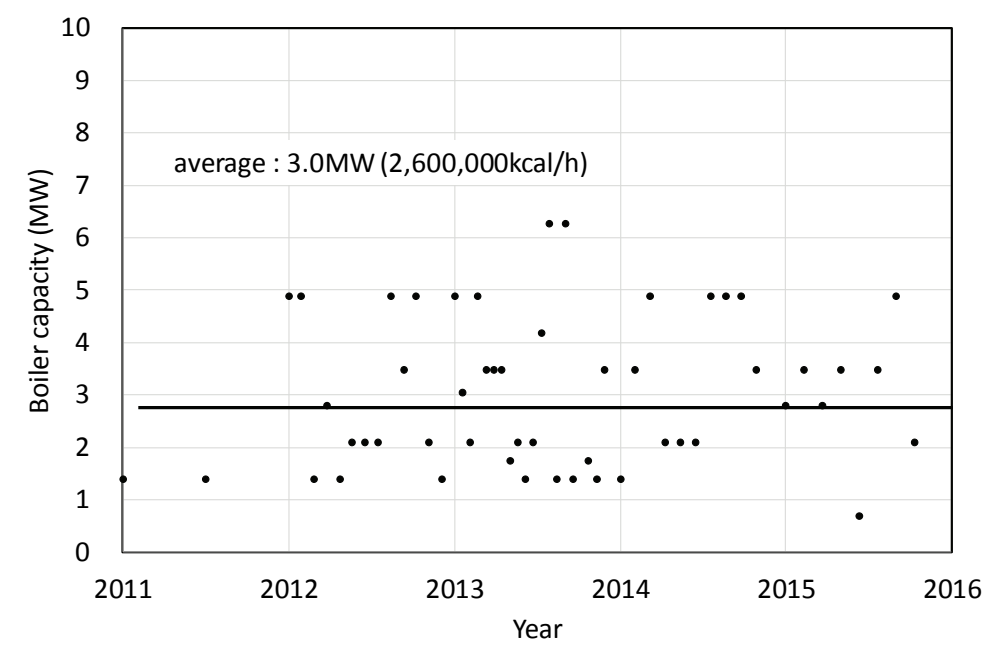

Fig. 2. Industrial wood pellet boiler thermal capacity with subsidy by Forest Service in Korea.

that Gwangju and Daegu among the metropolitan cities have many such boilers.

Fig. 2 shows the capacity of the installed industrial wood pellet boilers. The average capacity of these boilers is $3.0 \mathrm{MW}(2,600,000 \mathrm{kcal} / \mathrm{h})$, which is about $4.2 \mathrm{ton} / \mathrm{h}$ (wood pellet consumption is about $740 \mathrm{~kg} / \mathrm{h}$ based on the low-level heat generation of wood pellets at 4,100 kcal/h and the boiler efficiency at 85\%) if converted into the amount of steam generated. With low capacity boilers, 1.5 to $2 \mathrm{MW}$ wood pellet boilers have been widely installed, as well as $5.0 \mathrm{MW}$ boilers have also been installed in many places. Converted into steam generation, these capacities are about 2.5 ton/h as well as 7.0 ton/h. 


\subsection{Measurement method}

The study conducted the performance test of the KFS subsidized industrial wood pellet boiler by installing it based on the "Construction Inspection Standards for Industrial Wood Pellet Boilers” (KFS, 2013). When the boiler operation stabilized, the $\mathrm{O}_{2}, \mathrm{CO}$, and $\mathrm{NO}_{\mathrm{x}}$ concentration were measured for one hour using a portable multifunctional combustible gas meter (Testo 350), the results of which were averaged. Testo 350 can analyze various combustible gases $\left(\mathrm{O}_{2}, \mathrm{CO}, \mathrm{NO}_{\mathrm{x}}\right.$ and $\mathrm{SO}_{2}$, etc.) and allows for large amount of data records linked to a PC. The null adjustment was performed using the standard gas before the test to acquire the data reliability. The measurement scope of $\mathrm{O}_{2}$ is $0-25 \%$ at which the accuracy level is $\pm 0.01 \%$, and that of CO is $0-10000 \mathrm{ppm}$, and the accuracy level between 200 -2000 $\mathrm{ppm}$ is $\pm 5 \%$. The measurement scope of NO is $0-4000 \mathrm{ppm}$, and the accuracy level between 100 - $1999 \mathrm{ppm}$ is $\pm 5 \%$. Finally, the measurement scope of $\mathrm{NO}_{2}$ is $0-500 \mathrm{ppm}$, and the accuracy level between $100-500 \mathrm{ppm}$ is $\pm 5 \%$. The measured carbon monoxide and nitrogen oxide were converted into the value of the state of $12 \%$ of emission gas $\mathrm{O}_{2}$.

\section{RESULTS and DISCUSSION}

\subsection{Carbon monoxide (CO)}

Fig. 3 shows the carbon monoxide (CO) emissions from the installed industrial boilers by the year of installation. As has been shown, the average CO emission concentration from the installed industrial wood pellet boiler is $56 \mathrm{ppm}$ when the oxygen concentration in the emissions was $12 \%$. The maximum CO emission among the measured boilers was $220 \mathrm{ppm}$. High concentration of $\mathrm{CO}$ would lead to $\mathrm{CO}$ poisoning, causing nausea and in serious cases, death. There may be incomplete combustion or air is lacking in boilers. As shown in the figure, the $\mathrm{CO}$ emissions change by installation year. To clearly understand such a tendency, Fig. 4 shows the average $\mathrm{CO}$ emissions by taking five values based on the time of the CO emissions. Since 2012, the average CO emissions have decreased until 2015. While in 2012, it was within 50 - 100 ppm, in 2015, it decreased to $20-30 \mathrm{ppm}$. This is considerably below the allowable criteria of the air pollutants stipulated by the Enforcement Regulations of the Clean Air Conservation Act (at or below 200 ppm for facilities

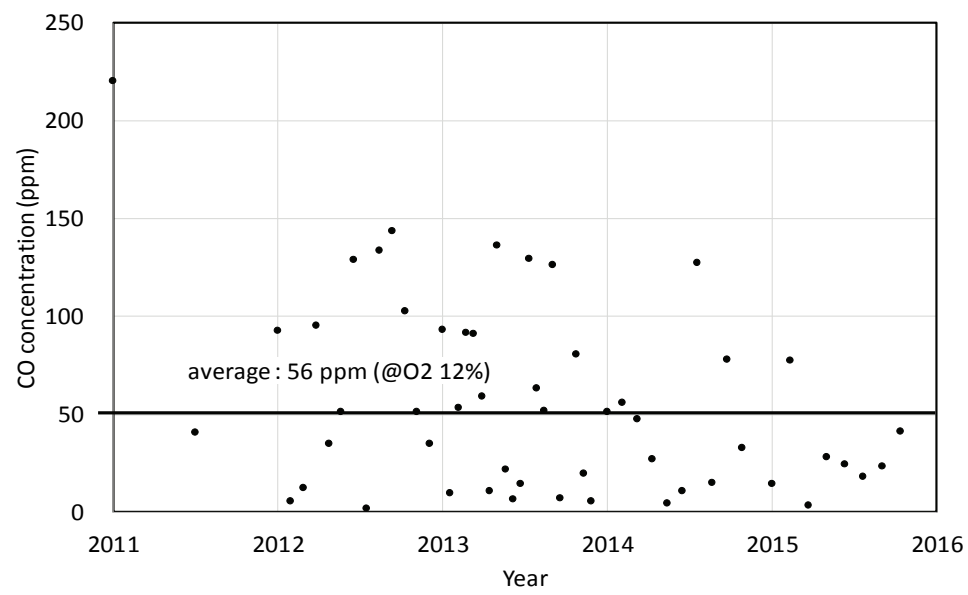

Fig. 3. CO emission of industrial wood pellet boiler according to the installation year. 
Analysis of Emission Characteristics and Emission Factors of Carbon Monoxide and Nitrogen Oxide Emitted from Wood Pellet Combustion in Industrial Wood Pellet Boilers Supplied According to the Subsidy Program of Korea Forest Service

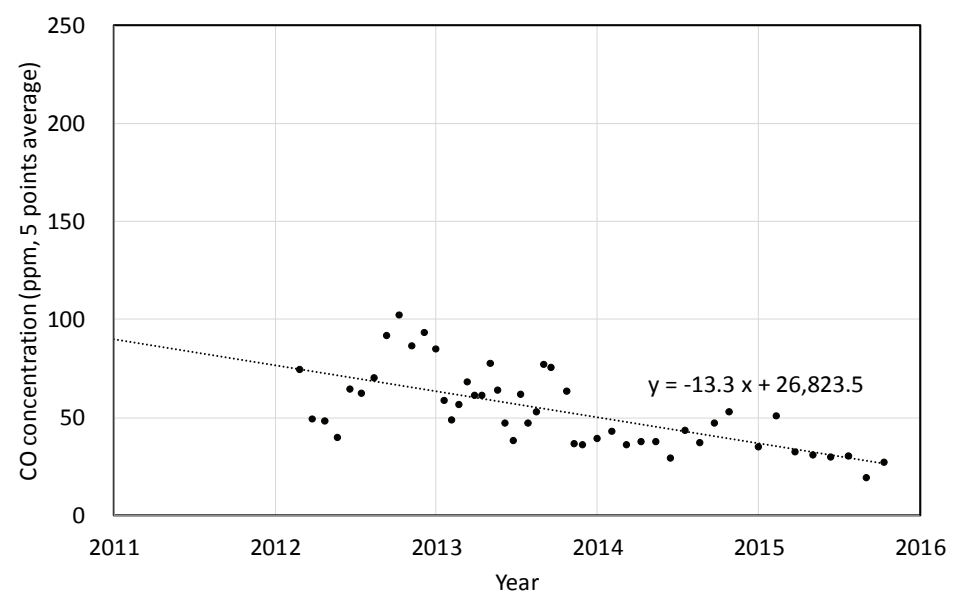

Fig. 4. Average CO emission of industrial wood pellet boiler according to the installation year.

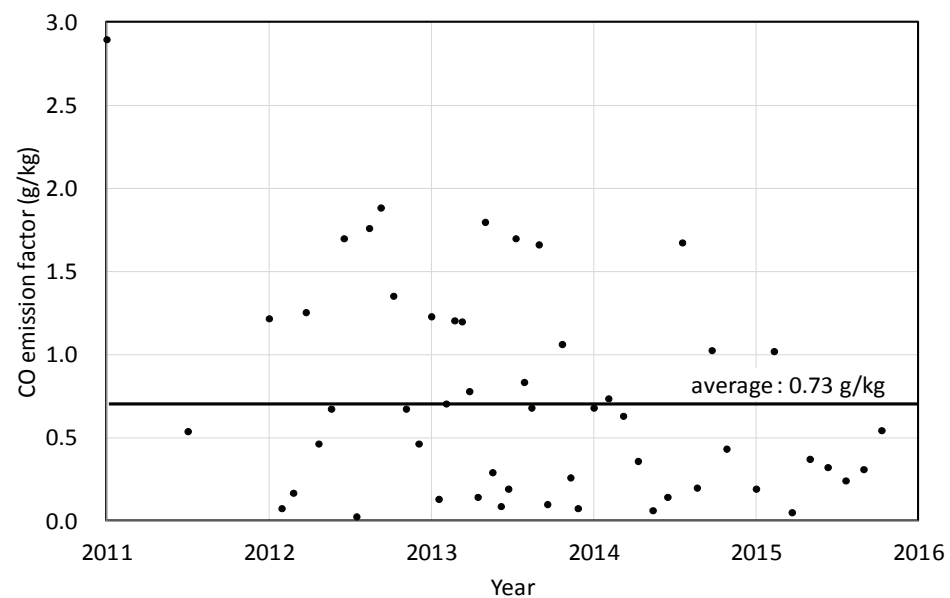

Fig. 5. CO emission factor of industrial wood pellet boiler according to the installation year.

using wood pellets). Generally, CO emissions decrease by reducing incomplete combustions through the optimization of the combustion system. It is believed that such $\mathrm{CO}$ emission reduction was due to the improvement of boiler efficiency and CO emissions reduction by boiler manufacturers since 2011 when industrial wood pellet boilers were distributed by KFS.

The study calculated the emission factor using the CO emission from the boiler. The emission factor for
$\mathrm{CO}$ or $\mathrm{NO}_{\mathrm{x}}$ (g/kg_fuel) is defined as the weight of the pollutant (g) emitted by the combustion of $1 \mathrm{~kg}$ of fuel, which can be determined by the following equation.

\section{Emission factor $(\mathrm{g} / \mathrm{kg})$}

$=$ pollutant concentration $\left(\mathrm{g} / \mathrm{m}^{3}\right) \times$ flue gas volume flow rate $\left(\mathrm{m}^{3} / \mathrm{h}\right) /$ fuel consumption $(\mathrm{kg} / \mathrm{h})$ 
In the equation above, the pollutant concentration is calculated by the emission concentration of each pollutant (ppm) measured at the time of the actual combustion of wood pellets, and the fuel consumption is the amount of fuel injected during the actual boiler operation. Finally, the gas emissions are based on the oxygen concentration in the emissions gas measured during the actual combustion of the boiler. Fig. 5 shows the $\mathrm{CO}$ emission factor for the industrial wood pellet boiler. The average $\mathrm{CO}$ emission factor of the distributed industrial wood pellet boiler is $0.73 \mathrm{~g} / \mathrm{kg}$. The average $\mathrm{CO}$ emissions of the industrial wood pellet boiler installed in 2015 was 25.7 ppm, which is considerably lower than $62.5 \mathrm{ppm}$, that of the wood pellet boiler installed in 2012. Such a trend can be verified in Fig. 5 which showed the CO emission factors by the time of installation where the $\mathrm{CO}$ emission factors decrease by the time of installation. The average $\mathrm{CO}$ emission factor of five industrial wood pellet boilers installed latest was very low at $0.36 \mathrm{~g} / \mathrm{kg}$.

\subsection{Nitrogen oxide $\left(\mathrm{NO}_{x}\right)$}

Fig. 6 shows the $\mathrm{NO}_{\mathrm{x}}$ emissions based on the nitrogen content contained in various types of wood chip fuel including the wood pellets used in this study (referring to the data by Kang et al., 2017). The figure shows the maximum and minimum values of $\mathrm{NO}_{\mathrm{x}}$ emissions measured when the nitrogen content of wood pellets used in the industrial boiler installed by the KSF's subsidy project was $0.3 \%$. It shows the tendency that the $\mathrm{NO}_{\mathrm{x}}$ value increases linearly based on the nitrogen content included in the fuel. Even the same wood fuels will have different $\mathrm{NO}_{\mathrm{x}}$ emissions based on the contained nitrogen content. However, wood pellets usually have nitrogen content below $0.5 \%$, and thus, the $\mathrm{NO}_{\mathrm{x}}$ content will become $100 \mathrm{ppm}$ or below. The study results on the $\mathrm{NO}_{\mathrm{x}}$ emissions characteristics based on the types of coal (bituminous coal and subbituminous coal) from a $500 \mathrm{MW}$ coal-fired boiler showed that the nitrogen content in coal is $0.76-1.7 \%$. As such, it was also confirmed that the emissions from a coal-fired plant were mainly thermal $\mathrm{NO}_{\mathrm{x}}$ emissions at high temperature, but when coal with high nitrogen content was used, the $\mathrm{NO}_{\mathrm{x}}$ generation increased.

Shown in Fig. 7 and Fig. 8 are the average of the five values of $\mathrm{NO}_{\mathrm{x}}$ emissions from industrial wood pellet boilers. The average $\mathrm{NO}_{\mathrm{x}}$ emissions measured from the boilers is $76 \mathrm{ppm}$ at $12 \%$ of the oxygen concentration. The $\mathrm{NO}_{\mathrm{x}}$ emissions were between 44 - 128 ppm, which

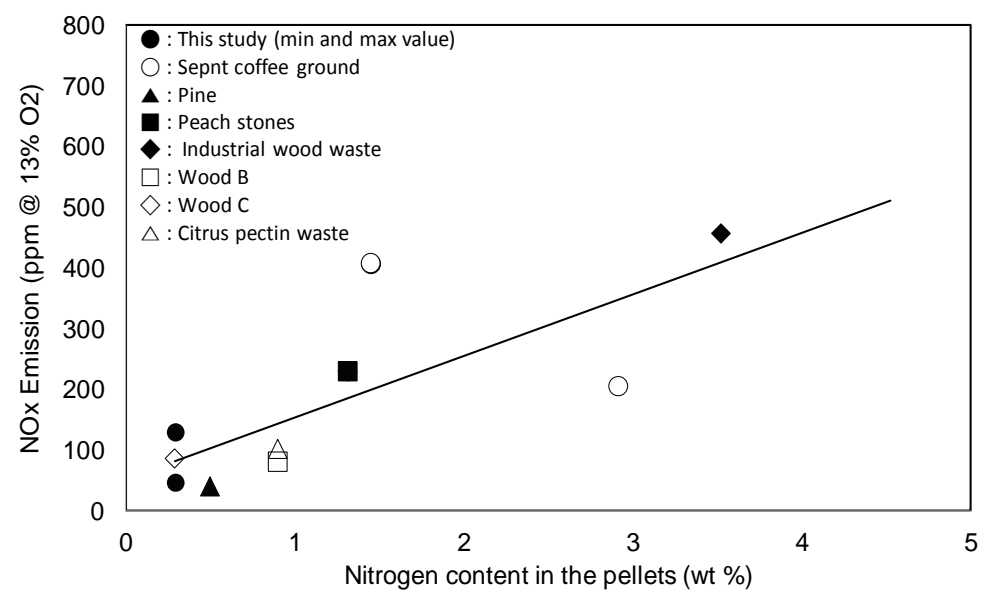

Fig. 6. Influence of the nitrogen content of the pellets on the $\mathrm{NO}_{\mathrm{x}}$ emissions. 
Analysis of Emission Characteristics and Emission Factors of Carbon Monoxide and Nitrogen Oxide Emitted from Wood Pellet Combustion in Industrial Wood Pellet Boilers Supplied According to the Subsidy Program of Korea Forest Service

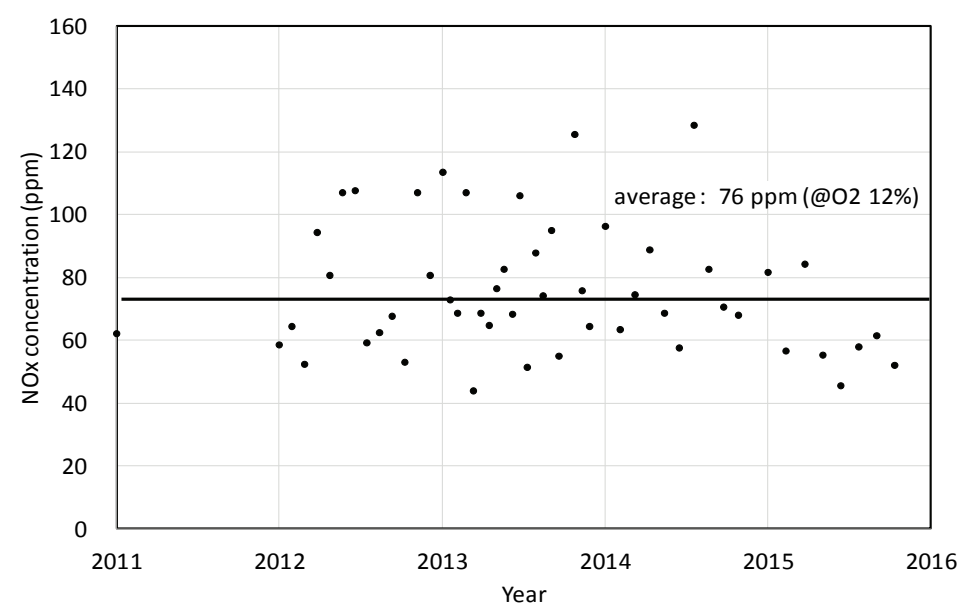

Fig. 7. $\mathrm{NO}_{\mathrm{x}}$ concentration of industrial wood pellet boiler according to the installation year.

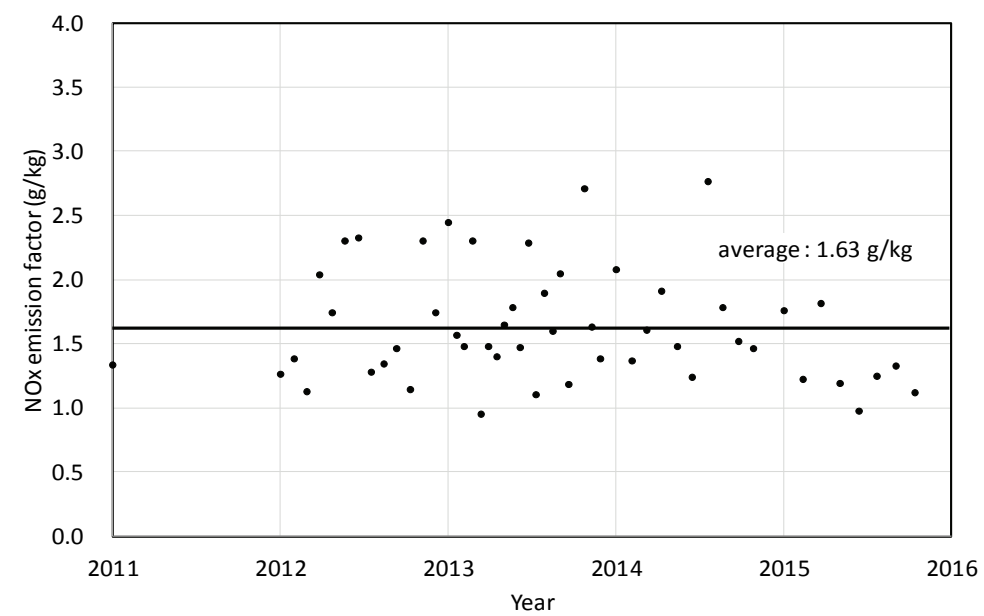

Fig. 8. $\mathrm{NO}_{\mathrm{x}}$ emission factor of industrial wood pellet boiler according to the installation year.

is considerably lower than the allowable standards of the air pollutants stipulated in the Enforcement Regulations of the Clean Air Conservation Act (at or below $150 \mathrm{ppm}$ of $\mathrm{NO}_{\mathrm{x}}$ for facilities that use wood pellets). At this point, the emission factor of $\mathrm{NO}_{\mathrm{x}}$ is $1.63 \mathrm{~g} / \mathrm{kg}$. The two figures do not show the tendency of the decrease in the emissions by the time of installation, as opposed to the CO distribution. This is because the CO emissions can be reduced by providing the optimal combustion conditions by improving the burner. However, for $\mathrm{NO}_{\mathrm{x}}$, wood pellets contain nitrogen by about 0.1 to $0.5 \%$, as opposed to LNG which does not contain nitrogen $(\mathrm{N})$. Such nitrogen is oxidized via the combustion at high temperature and turned into $\mathrm{NO}$ and $\mathrm{NO}_{2}$ among others. Such generated $\mathrm{NO}_{\mathrm{x}}$ is called fuel NOx, which is fundamentally difficult 
Sea Byul Kang $\cdot$ Kyu Sung Choi $\cdot$ Hyun Hee Lee $\cdot$ Gyu-Seong Han

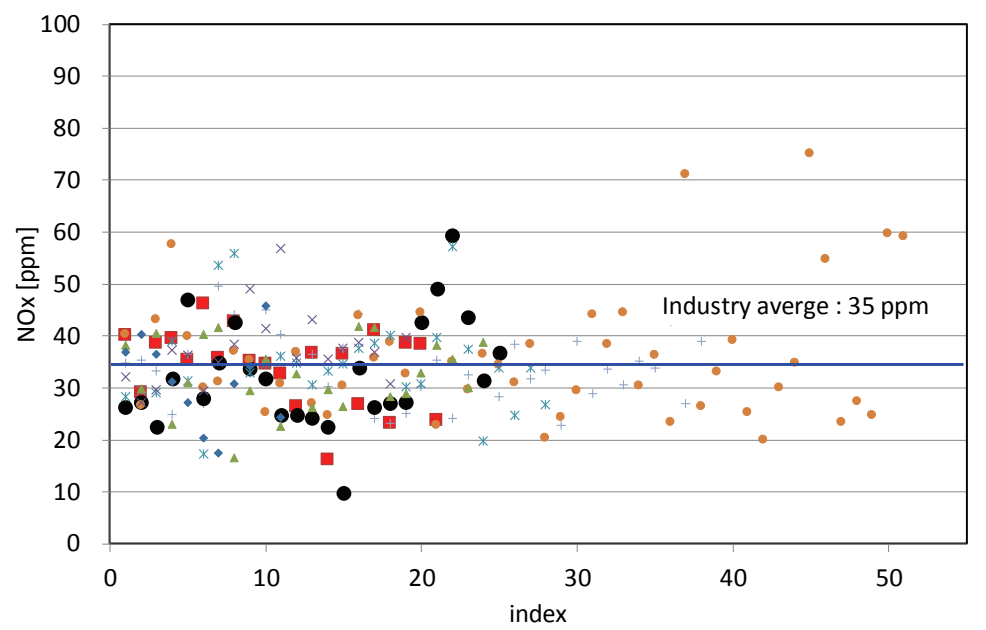

Fig. 9. $\mathrm{NO}_{\mathrm{x}}$ concentration of low $\mathrm{NO}_{\mathrm{x}}$ burners in Korea (Ministry of Environment of Korea).

Table 1. $\mathrm{NO}_{\mathrm{x}}$ emission factors of wood pellet, LNG, coal and bunker-C fuel

\begin{tabular}{ccccc}
\hline Fuel type & NOx (ppm) & $\mathrm{O}_{2}(\%)$ & $\mathrm{NO}_{\mathrm{x}}$ emission factor $(\mathrm{g} / \mathrm{kg})$ & Based on LNG \\
\hline \hline LNG & 35 & 3 & 0.96 & 1.00 \\
Wood pellet & 67 & 13 & 1.82 & 1.90 \\
$\begin{array}{c}\text { Coal or bunker-C with } \\
\text { de-NO } \mathrm{NO}_{\mathrm{x}} \text { facility }\end{array}$ & 70 & 3 & 1.98 & 2.06 \\
\hline
\end{tabular}

Note: $\mathrm{NO}_{\mathrm{x}}$ emission of LNG is average of those of low $\mathrm{NO}_{\mathrm{x}}$ burners and $\mathrm{NO}_{\mathrm{x}}$ emission of Coal or bunker-C with de- $\mathrm{NO}_{\mathrm{x}}$ facility is referred to the exhaust gas regulation standard of Clean Air Conservation Act.

to decrease, and due to such characteristics, $\mathrm{NO}_{\mathrm{x}}$ emissions tend not to decrease.

Shown in Fig. 9 are the $\mathrm{NO}_{\mathrm{x}}$ emissions on domestic low- $\mathrm{NO}_{\mathrm{x}}$ certified products. As shown in the figure, the average $\mathrm{NO}_{\mathrm{x}}$ is $35 \mathrm{ppm}$. The low- $\mathrm{NO}_{\mathrm{x}}$ burner criterial for industrial boilers is below $40 \mathrm{ppm}$ at $4 \%$ of oxygen concentration. Generally, the LNG burner that satisfies the low- $\mathrm{NO}_{\mathrm{x}}$ burner criteria is around $35 \mathrm{ppm}$ at 3\% of oxygen concentration.

Shown in Table 1 are the average $\mathrm{NO}_{\mathrm{x}}$ emission factors under the normal combustion of boilers with LNG, wood pellets, and coal (or bunker-C). In case of wood pellets, the average $\mathrm{NO}_{\mathrm{x}}$ value emitted from the industrial wood pellet boiler, measured previously used. Coal-fried or bunker-C-fired boilers run with $\mathrm{NO}_{\mathrm{x}}$ at or below $70 \mathrm{ppm}$ (facilities installed before December 2014, Clean Air Conservation Act). Assuming that such a condition was the representative situation for each fuel, the $\mathrm{NO}_{\mathrm{x}}$ emission factors could be calculated, which are shown in Table 1 . When the $\mathrm{NO}_{\mathrm{x}}$ emission index of LNG is set to 1 , that of wood pellets is 1.90 , and coal or bunker-C is 2.01. For coal or bunker-C, it was assumed that there would be post-processing facilities to reduce $\mathrm{NO}_{\mathrm{x}}$ such as SCR (selective catalytic reduction) at the end of the boiler. Otherwise, the emission index would have been higher. 
Analysis of Emission Characteristics and Emission Factors of Carbon Monoxide and Nitrogen Oxide Emitted from Wood Pellet Combustion in Industrial Wood Pellet Boilers Supplied According to the Subsidy Program of Korea Forest Service

\section{CONCLUSION}

The $\mathrm{CO}$ and $\mathrm{NO}_{\mathrm{x}}$ measurement values of 63 KFSsubsidized industrial wood pellet boilers between 2011 and 2015 all satisfied the allowable criteria by the Ministry of Environment. Based on the $\mathrm{CO}$ and $\mathrm{NO}_{\mathrm{x}}$ emissions values, the emission factors of industrial wood pellet boilers were calculated and compared with $\mathrm{NO}_{\mathrm{x}}$ emitted from the low- $\mathrm{NO}_{\mathrm{x}}$ certified burner. The analyzed results are summarized as follows.

1. The average capacity of the KFS-subsidized industrial wood pellet boilers was 3.0 MW, and the wood pellet consumption was about $740 \mathrm{~kg} / \mathrm{h}$.

2. The average $\mathrm{CO}$ emission from the industrial wood pellet boilers distributed for the five years was 56 ppm (@O 12\%), which can be converted into the emission factor at $0.73 \mathrm{~g} / \mathrm{kg}$.

3. The average CO emission from the industrial wood pellet boilers installed in 2012 during the early period of the subsidy program was 70.3 ppm (@ $\mathrm{O}_{2}$ $12 \%)$, but that from the boilers installed at the ending year of the subsidy program was $28.9 \mathrm{ppm}$. Such a result is determined to be due to the optimization of the burner and boiler system through technical development.

4. The average $\mathrm{NO}_{\mathrm{x}}$ emission from the industrial wood pellet boilers installed for the five years was 76 ppm (@O 12\%), which can be converted into the emission factor at $1 / 63 \mathrm{~g} / \mathrm{kg}$.

5. $\mathrm{NO}_{\mathrm{x}}$ did not show the tendency of reduction by time. It is determined that this is because fuel $\mathrm{NO}_{\mathrm{x}}$ generation did not decrease along with the nitrogen content included in the fuel.

6. The $\mathrm{NO}_{\mathrm{x}}$ emission factor from the industrial wood pellet boilers was compared to that from low- $\mathrm{NO}_{\mathrm{x}}$ certified LNG burner and coal (bunker- C)-fired burners. The former was about 1.90 times higher than that of the latter and was about 0.92 times lower than the coal- or bunker-C-fired boilers with denitrification facilities.

\section{REFERENCES}

Kang, K., Song, J., Yoon, M., Lee, B., Kim, S., Chang, Y., Jeon, C. 2009. A Numerical Study on the Effects of SOFA on $\mathrm{NO}_{x}$ Emission Reduction in 500MW Class Sub-bituminous Coal-Fired Boiler. of the Korean Society of Mechanical Engineers - B 33(11): 858-868.

Kang, S.B., Oh, H.Y., Kim, J.J., Choi, K.S. 2017. Characteristics of spent coffee ground as a fuel and combustion test in a small boiler $(6.5 \mathrm{~kW})$. Renewable Energy 113: 1208-1214.

Kim, K.H. 2017. Wood Pellet - Renewable energy? Ultra fine dust 20 times, http://news.kbs.co.kr/news/ view.do?ncd=3559653, Seoul, Korea.

Kim, S.H., Yang, I., Han, G.-S. 2015. Effect of sawdust moisture content and particle size on the fuel characteristics of wood pellet fabricated with Quercus mongolica, Pinus densiflora and Larix kaempferi Sawdust. Journal of the Korean Wood Science and Technology 43(6): 757-767.

Korea Forest Service. 2013. Construction Inspection Standards for Industrial Wood Pellet Boilers. Daejeon, Korea.

Korea Forest Service. 2015. Industrial Wood Pellet Boiler Subsidy Standards, Daejeon, Korea.

Korea Standards and Certifications, 2014, Land Boilers - Heat Balancing (KS B 6205).

Ministry of Environment. 2017. Clean Air Conservation Act, ME, Sejong, Korea.

Yang, I., Chae, H.-G., Han, G.-S. 2017. Effect of bark and drying waste liquor of Larix kaempferi used as an additive on the fuel characteristics of wood pellet fabricated with Rigida pine and Quercus mongolica sawdust, Journal of the Korean Wood Science and Technology 45(3): 258-267. 


\title{
APPENDIX
}

\author{
(Korean Version)
}

\section{산림청 지원사업에 따라 보급된 산업용 목재펠릿보일러에서 목재펠릿 연소 시 배출되는 일산화탄소와 질소산화물의 배출 특성 및 배출계수 분석}

요약 : 산림청은 보조금 지원사업을 통해 2011년부터 2015년까지 76대의 산업용 목재펠릿보일러를 보급하였다. 보일러의 연소 시 발생하는 일산화탄소(CO) 및 질소산화물 $\left(\mathrm{NO}_{\mathrm{x}}\right)$ 는 각각 급성 중독 시 사망에까지 이르게 하는 물질이기 때문에 배출량을 줄이는 것이 매우 중요하다. 따라서 이들 보일러 중 열풍기와 초기에 보급된 일부 보일러를 제외한 63대의 보일러에 서 배출된 $\mathrm{CO}$ 및 $\mathrm{NO}_{\mathrm{x}}$ 계측값을 분석하였다. 또한 측정된 배출가스 농도(배기가스 $\mathrm{O}_{2}$ 농도 $12 \%$ 기준)로부터 배출계수를 산출하였다. 산업용 목재펠릿보일러에서 배출된 $\mathrm{CO}$ 의 평균값은 $49 \mathrm{ppm}$ 이었으며, 해를 거듭함에 따라 $\mathrm{CO}$ 의 농도가 줄어들 고 있음이 확인되었다. 이때 $\mathrm{CO}$ 의 배출계수는 $0.73 \mathrm{~g} / \mathrm{kg}$ 였다. 산업용 목재펠릿보일러에서 배출된 $\mathrm{NO}_{x}$ 의 평균값은 $67 \mathrm{ppm}$ 였 으며, $\mathrm{NO}_{\mathrm{x}}$ 의 배출계수는 $1.63 \mathrm{~g} / \mathrm{kg}$ 이었다. $\mathrm{CO}$ 와는 달리 설치년도에 따라 감소하는 경향은 나타나지 않았다. $\mathrm{CO}$ 및 $\mathrm{NO}_{\mathrm{x}}$ 계측값은 모두 환경부의 허용기준을 만족하였다. 이러한 $\mathrm{NO}_{\mathrm{x}}$ 배출계수를 저 $\mathrm{NO}_{\mathrm{x}}$ 인증된 연소기에서 생성되는 $\mathrm{NO}_{\mathrm{x}}$ 배출계수 와 비교하였다. 산업용 목재펠릿보일러의 $\mathrm{NO}_{\mathrm{x}}$ 배출계수는 저 $\mathrm{NO}_{\mathrm{x}}$ 인증된 $\mathrm{LNG}$ 연소기의 $\mathrm{NO}_{\mathrm{x}}$ 배출계수에 비해 약 1.9 배, 석탄 연소에 비해 약 0.92 배였다.

\section{1. 서 론}

산림청은 2011년부터 2015년까지 신재생에너지인 목재펠릿 소비량을 확대하여 저탄소 녹색 성장에 기여하고자 산업용 목재펠릿 보일러 보급 및 설치를 지원해왔다. 이를 통해 국내의 산업용 목재펠릿보일러 기술 수준을 한 단계 높이는데 기여했으 며, 동 기간 중 76대의 산업용 목재펠릿 연소기가 설치되었다. 산업용 목재펠릿보일러의 효율적인 보급 관리를 위하여, 산림청은 산업용 목재펠릿보일러 지원 기준(KFS, 2015), 산업용 목재펠릿보일러 준공검사를 위한 시험기준(KFS, 2013)을 책정하였다. 이에 따른 지원 대상의 산업용 목재펠릿 연소기는 $0.5-7.0 \mathrm{ton} / \mathrm{h}$ 급 스팀 보일러 또는 $230 \mathrm{~kW}$ 이상 온수 보일러 및 열풍기이다. 이중에서 63대는 스팀 보일러였으며, 7대는 온수보일러, 6대는 열풍기였다. 목재 펠릿 보일러에 대한 보조금을 지원받기 위해서 는 다음과 같은 조건을 만족하여야 한다. 1) 보일러 열효율은 저위발열량 기준 $85 \%$ 이상, 2) 역화방지장치 등 안전장치에 대한 구비 3) 대기 오염물질 중 하나인 일산화탄소(CO) 배출량이 $200 \mathrm{ppm}$ 미만 등이 있다.

목재펠릿의 연소에 따른 대기오염물질과 관련된 국내 규정으로는 대기환경보전법이 있다(ME, 2017). 일정 규모 이상의 큰 연소설비에서 발생되는 배출물에 대하여 현재 대기환경보전법에 명시되어 있는 적용 대상은 1) 목재펠릿 제조시설(선별시설, 건조· 가열시설, 파쇄· 분쇄시설, 압축·성형시설) 중 연료사용량이 시간당 $30 \mathrm{~kg}$ 이상이거나, 용적이 $3 \mathrm{~m}^{3}$ 이상이거나, 동력이 $2.25 \mathrm{~kW}$ (파쇄 · 분쇄시설은 $15 \mathrm{~kW}$ ) 이상인 시설과, 2) 목재펠릿 사용시설 중 연료제품 사용량이 시간당 $200 \mathrm{~kg}$ 이상인 시설(다른 연료와 목재펠릿을 함께 연소하는 시설은 제외)이다(ME, 2017).

2015년부터 적용된 대기오염물질의 허용기준을 살펴보면, 목재펠릿 사용시설에서의 CO 농도는 $200 \mathrm{ppm}$ 이하(실측산소농도 $12 \%)$ 이어야 한다. 질소산화물 $\left(\mathrm{NO}_{\mathrm{x}}, \mathrm{NO}_{2}\right.$ 로서 $)$ 은 목재펠릿 제조시설 중 건조·가열시설의 경우 $100 \mathrm{ppm}$ 이하, 목재펠릿 사용시 설에서 $150 \mathrm{ppm}$ 이하(실측산소농도 $12 \%$ ) 이어야 한다. 미세먼지는 목재펠릿 제조시설 중 건조·가열시설의 경우 $50 \mathrm{mg} / \mathrm{Sm}$ 이하, 목재펠릿 사용시설에서 $50 \mathrm{mg} / \mathrm{Sm}^{3}$ 이하(실측산소농도 12\%) 이어야 한다(ME, 2017). 목재펠릿의 경우 연료 특성 상 황산화물 및 중금속 등의 함유율이 매우 낮기 때문에 이에 대한 하용기준이 설정되어 있지 않다.

2017년 국정감사장에서는 목재펠릿의 연소 실험 결과 초미세먼지를 유발하는 질소산화물이 연탄의 20배나 발생한다는 내용의 주장이 제기되었고, 검증이 되지 않은 채 이 내용이 인용되어 보도됨으로써 사회적인 논란이 일었다(kim, 2017). 이는 국내에서 목재펠릿 제조 특성에 관한 연구는 이루어져 왔으나(Kim et al., 2015, Yang et. al., 2017), 목재펠릿 연소 시 발생하는 대기오염물질에 관한 연구가 그동안 거의 없었기 때문이다. 
Analysis of Emission Characteristics and Emission Factors of Carbon Monoxide and Nitrogen Oxide Emitted from Wood Pellet Combustion in Industrial Wood Pellet Boilers Supplied According to the Subsidy Program of Korea Forest Service

본 연구에서는 산림청에서 지원한 목재펠릿보일러에 대하여 연소 시 배출되는 대기오염물질을 측정하고자 하였다. 이를 통해 산업용 목재펠릿보일러가 환경부의 대기오염물질 허용기준에 부합하는지를 확인하였다. 또한 대기오염물질의 배출값을 기반으로 하여 산업용 목재펠릿보일러의 배출계수를 산출하였으며, 이를 저 $\mathrm{NO}_{\mathrm{x}}$ 인증버너에서 배출되는 $\mathrm{NO}_{\mathrm{x}}$ 와 비교하였다.

\section{2. 재료 및 방법}

\section{1 조사 대상}

산림청에서 지원한 산업용 목재펠릿보일러(스팀보일러, 온수보일러, 열풍기)는 2011년에 9대, 2012년에 27대, 2013년에 21대, 2014년에 10대, 2015년에 9대였다. 이들 보일러 중 열풍기와 초기에 보급된 일부 보일러를 제외한 63대의 보일러를 측정 대상으로 하였다. Fig. 1은 이들 산업용 목재펠릿 보일러의 지역별 설치현황을 보여준다. 지원받은 산업용 목재펠릿보일러 의 $50 \%$ 이상이 경기도와 경상남북도에 설치되었다. 이는 산업용 보일러의 수요가 많은 공장 등 산업단지가 많이 있는 지역에 지원받고자 하는 업체가 많기 때문으로 판단된다. 광역시 중에서는 광주와 대구에 설치가 많이 된 것을 알 수 있다.

설치된 산업용 목재펠릿보일러의 용량을 Fig. 2에 나타내었다. 산업용 목재펠릿보일러의 평균 용량은 $3.0 \mathrm{MW}(2,600,000$ $\mathrm{kcal} / \mathrm{h}$ )이며 이는 증기 발생량으로 환산하면 약 $4.2 \mathrm{ton} / \mathrm{h}$ (목재 펠릿 소비량은 약 $740 \mathrm{~kg} / \mathrm{h}$ 임. 목재펠릿 저위발열량 4,100 $\mathrm{kcal} / \mathrm{h}$ 및 보일러 효율 $85 \%$ 가정)이다. 용량이 작은 경우는 대부분 $1.5-2 \mathrm{MW}$ 용량의 목재펠릿보일러가 많이 설치되었으며, $5.0 \mathrm{MW}$ 급도 많이 설치된 것을 알 수 있다. 증기 생산량으로 환산하면 약 $2.5 \mathrm{ton} / \mathrm{h}$ 급이 많이 설치되었고 대형으로는 7.0 ton/h급이 많이 설치된 것을 알 수 있다.

\section{2 측정 방법}

산림청에서 지원한 산업용 목재펠릿보일러에 대해 “산업용 목재펠릿 보일러 준공검사를 위한 시험기준(KFS, 2013)”에 의거 하여 설치 완료 후 보일러 성능 시험을 수행하였다. 보일러의 운전 상태가 안정화 되었을 때 휴대형 다기능 연소가스측정기(Testo $350)$ 를 사용하여 산소 $\left(\mathrm{O}_{2}\right), \mathrm{CO}, \mathrm{NO}_{x}$ 의 농도를 1 시간 이상 측정하여 측정값을 평균하였다. Testo 350 은 다수의 연소가스 $\left(\mathrm{O}_{2}\right.$, $\mathrm{CO}, \mathrm{NO}_{\mathrm{x}}, \mathrm{SO}_{2}$ 등)를 분석할 수 있는 기기로서, $\mathrm{PC}$ 연결을 통한 대량의 데이터 기록이 가능하다. 측정 전 표준가스를 통해 영점 조정을 진행하여 데이터의 신뢰성을 확보하였다. $\mathrm{O}_{2}$ 의 측정범위는 $0-25 \%$ 이며, $0-25 \%$ 범위에서의 정확도는 $\pm 0.01 \%$ 이다. $\mathrm{CO}$ 의 측정범위는 0-10000 ppm 이며, 200-2000 ppm 범위에서의 정확도는 $\pm 5 \%$ 이다. NO의 측정범위는 0-4000 ppm 이며, 100-1999 ppm 범위에서의 정확도는 $\pm 5 \%$ 이다. 또한 $\mathrm{NO}_{2}$ 의 측정범위는 0-500 ppm 이며, $100-500 \mathrm{ppm}$ 범위에서의 정확도는 $\pm 5 \%$ 이다. 계측된 일산화탄소와 질소산화물은 배기가스 $\mathrm{O}_{2} 12 \%$ 로 환산하여 나타내었다.

\section{3. 결과 및 고찰}

\section{1 일산화탄소 $(\mathrm{CO})$}

설치된 산업용 보일러에 대해 일산화탄소 배출량을 측정결과를 설치된 연도순으로 Fig. 3에 나타냈다. 그림에서 확인할 수 있듯이 설치된 산업용 목재펠릿보일러의 CO 평균 배출 농도는 배기가스 중 산소의 농도를 $12 \%$ 로 환산하였을 때 $56 \mathrm{ppm}$ 이다. 측정된 보일러들 중 최대 $\mathrm{CO}$ 배출량은 $220 \mathrm{ppm}$ 이다. $\mathrm{CO}$ 의 경우 농도가 높게 되면 $\mathrm{CO}$ 중독을 유발시켜 어지럼증 및 심각할 경우에는 사망까지 유발하는 물질로 알려져 있다. 보일러에서 $\mathrm{CO}$ 는 연소가 원활이 일어나지 않는 경우나 연소용 공기가 부족한 경우 다량 발생한다. 그림에서 확인할 수 있듯이 CO 배출량은 설치년도에 따라 변화하고 있는 것을 알 수 있다. 이러한 경향을 보다 명확히 보기위해 일산화탄소 배출 시간에 따라 5개씩 평균을 구하여 CO 평균 배출량을 구하여 Fig. 4에 나타냈다. 2012년 이후 CO 평균 배출량이 2015년까지 계속 줄어들고 있는 것을 알 수 있다. 2012년에는 50 - 100 ppm의 범위로 배출되고 있으나, 2015년에는 배출량이 20 - $30 \mathrm{ppm}$ 으로 낮아지고 있다. 이는 대기환경보전법 시행규칙에 규정된 대기오염물질의 허용기 준(목재펠릿 사용시설 CO $200 \mathrm{ppm}$ 이하)을 훨씬 밑도는 값이다. 일반적으로 CO 배출은 연소시스템에 대한 최적화를 통해 불완전연소를 줄이게 되면 저감된다. 이와 같은 $\mathrm{CO}$ 배출량 감소는 산림청에서 산업용 목재펠릿보일러가 보급되기 시작한 2011년 이후 보일러 제작업체마다 보일러 효율 향상, CO 저감 등 기술개발에 집중하였기 때문으로 판단된다.

보일러에서 배출된 $\mathrm{CO}$ 값을 사용하여 배출계수를 계산해 보았다. $\mathrm{CO}$ 나 $\mathrm{NO}_{\mathrm{x}}$ 등에 대한 배출계수 $(\mathrm{g} / \mathrm{kg}$ fuel)는 연료 $1 \mathrm{~kg}$ 을 연소시켰을 때 배출되는 오염물질의 무게(g)로 정의되며, 아래와 같은 식으로 계산할 수 있다. 
Emission factor $(\mathrm{g} / \mathrm{kg})=$ pollutant concentration $\left(\mathrm{g} / \mathrm{m}^{3}\right) *$ flue gas volume flow rate $\left(\mathrm{m}^{3} / \mathrm{h}\right) /$ fuel consumption $(\mathrm{kg} / \mathrm{h})$ 위 식에서 오염물질 배출량(pollutant concentration)은 실제 목재펠릿 연소 시 계측된 각 오염물질의 배출 농도(ppm)로부터 계산되며, 연료 소비량은 실제 보일러 가동 시 투입되는 연료량을 사용하였다. 마지막으로 배기가스 배출량은 실제 보일러 연소 시 계측된 배기가스 산소농도를 기반으로 하여 계산하였다. Fig. 5에는 산업용 목재펠릿보일러에 대한 CO 배출계수를 나타냈다. 보급된 산업용 목재펠릿보일러의 평균 CO 배출계수는 $0.73 \mathrm{~g} / \mathrm{kg}$ 이다. 2015년에 설치된 산업용 목재펠릿보일러의 $\mathrm{CO}$ 평균 배출량은 $25.7 \mathrm{ppm}$ 으로 초기(2012)에 설치된 목재펠릿보일러의 CO 평균 배출량인 $62.5 \mathrm{ppm}$ 에 비해 매우 낮다. 이러한 경향은 $\mathrm{CO}$ 배출계수를 설치된 시간 순으로 나타낸 Fig. 5에서도 설치년도에 따라 CO 배출계수가 줄어들고 있는 것을 확인할 수 있다. 가장 마지막에 설치된 5개 산업용 목재펠릿보일러의 CO 배출계수의 평균은 $0.36 \mathrm{~g} / \mathrm{kg}$ 로 매우 낮다.

\section{2 질소산화물 $\left(\mathrm{NO}_{\mathrm{x}}\right)$}

본 연구에서 사용한 목재펠릿을 포함한 여러 종류의 목질계 고형 연료에 포함된 질소 함량에 따른 $\mathrm{NO}_{\mathrm{x}}$ 배출량을 Fig. 6 에 나타냈다(Kang et al., 2017의 자료 인용). 그림에서 산림청 보급사업에 의해 설치된 산업용 보일러에서 사용된 목재펠릿의 질소함량이 $0.3 \%$ 일 때 측정된 $\mathrm{NO}_{\mathrm{x}}$ 배출량의 최댓값과 최솟값을 나타냈다. 연료에 포함된 질소 함량에 따라 $\mathrm{NO}_{\mathrm{x}}$ 값이 선형적으 로 증가하는 경향을 확인할 수 있다. 같은 목재 연료라고 하더라도 그 연료에 포함된 질소 함량에 따라 $\mathrm{NO}_{\mathrm{x}}$ 생성량이 달라질 것이다. 그런데 목재 펠릿의 경우 대부분 질소 함량이 $0.5 \%$ 미만이기 때문에 $\mathrm{NO}_{x}$ 생성은 $100 \mathrm{ppm}$ 이하가 될 것이다. 500MW급 석탄화력보일러에서 석탄 종류(역청탄, 아역청탄)에 따른 $\mathrm{NO}_{\mathrm{x}}$ 배출특성 연구 결과를 살펴보면(Kang et al., 2009), 석탄에 포함된 질소 함량은 $0.76-1.7 \%$ 수준이다. 이로 인해 석탄화력 발전소에서는 고온에서 발생하는 thermal $\mathrm{NO}_{\mathrm{x}}$ 생성이 큰 부분을 차지하지만, 질소성분이 높은 석탄을 연소시켰을 때 $\mathrm{NO}_{\mathrm{x}}$ 생성이 높아진다는 사실도 확인되었다.

산업용 목재펠릿보일러에 대한 $\mathrm{NO}_{\mathrm{x}}$ 배출량 및 5 개 평균한 값을 Fig. 7과 8에 나타냈다. 계측된 보일러의 평균 $\mathrm{NO}_{\mathrm{x}}$ 배출량은 배기가스 산소농도 $12 \%$ 에서 $76 \mathrm{ppm}$ 이다. $\mathrm{NO}_{x}$ 의 경우 44-128 ppm까지 분포되어 있는 것을 알 수 있다. 이는 대기환경보전법 시행규칙에 규정된 대기오염물질의 허용기준(목재펠릿 사용시설 $\mathrm{NO}_{\mathrm{x}} 150 \mathrm{ppm}$ 이하)을 횔씬 밑도는 값이다. 이 때 $\mathrm{NO}_{\mathrm{x}}$ 에 대한 배출계수를 계산해보면 $1.63 \mathrm{~g} / \mathrm{kg}$ 이다. 두 그림을 보면 설치 기간에 따른 $\mathrm{CO}$ 분포와는 달리 시간이 지남에 따라 배출량이 줄어드는 경향은 없다. 이러한 이유를 살펴보면 CO 배출은 연소기를 개선하여 최적연소 조건을 만들어주어 저감할 수 있다. 하지만 $\mathrm{NO}_{x}$ 의 경우 연료에 질소 $(\mathrm{N})$ 성분이 없는 천연가스(LNG)와는 달리 목재펠릿에 $0.1-0.5 \%$ 정도 질소가 포함되어 있다. 이러한 질소가 고온의 연소분위기에서 산화되어 $\mathrm{NO}$ 와 $\mathrm{NO}_{2}$ 등으로 변하게 된다. 이렇게 생성된 $\mathrm{NO}_{\mathrm{x}}$ 를 $\mathrm{Fuel} \mathrm{NO}_{\mathrm{x}}$ 라 한다. 이러한 $\mathrm{NO}_{\mathrm{x}}$ 는 근본적으로 줄이기 힘들게 되며 이러한 특성으로 인해 $\mathrm{NO}_{\mathrm{x}}$ 배출량은 줄어들지 않는 경향을 나타내게 된다.

국내 저 $\mathrm{NO}_{\mathrm{x}}$ 인증제품에 대한 $\mathrm{NO}_{\mathrm{x}}$ 배출값을 Fig. 9에 나타냈다. 그림에서 보는 것과 같이 $\mathrm{NO}_{\mathrm{x}}$ 평균값은 $35 \mathrm{ppm}$ 인 것을 알 수 있다. 산업용 보일러에 대한 저 $\mathrm{NO}_{\mathrm{x}}$ 버너 기준은 배기가스 산소농도 $4 \%$ 에서 $40 \mathrm{ppm}$ 미만이다. 일반적으로 저 $\mathrm{NO}_{\mathrm{x}}$ 버너기준을 만족하는 LNG 버너는 산소농도 $3 \%$ 에서 $35 \mathrm{ppm}$ 정도 배출되고 있다.

$\mathrm{LNG}$, 목재펠릿 및 석탄(또는 중유)에 대한 보일러 정상 연소 시의 평균적인 $\mathrm{NO}_{\mathrm{x}}$ 배출계수를 Table 1에 나타냈다. 목재펠릿의 경우 앞에서 측정한 산업용 목재펠릿 보일러에서 배출되는 $\mathrm{NO}_{\mathrm{x}}$ 평균값을 사용하였다. 석탄 또는 중유(bunker-C)를 사용하는 발전용 보일러의 경우 일반적으로 $\mathrm{NO}_{\mathrm{x}}$ 를 $70 \mathrm{ppm}$ 이하로 운전되고 있다(대기환경보존법 2014.12 이전 설치설비). 이러한 상황을 각 연료의 대표적인 상황으로 가정하였을 때 $\mathrm{NO}_{\mathrm{x}}$ 배출 계수를 계산하여 Table 1에 나타냈다. $\mathrm{LNG}$ 의 $\mathrm{NO}_{\mathrm{x}}$ 배출지수를 1 로 하였을 때 목재펠릿은 1.90 배, 석탄 또는 bunker-C의 경우 2.01 배 배출되는 것으로 계산되었다. 석탄 또는 bunker-C의 경우 보일러 후단에 SCR(selective catalytic reduction) 등 $\mathrm{NO}_{x}$ 를 저감시키기 위한 후처리 설비가 있는 경우로 가정하였다. 만일 SCR 등 후처리 설비가 없을 경우에는 배출계수가 더 높을 것이다.

\section{4. 결 론}

2011년부터 2015년까지 산림청에서 지원한 산업용 목재펠릿보일러 63대의 $\mathrm{CO}$ 및 $\mathrm{NO}_{\mathrm{x}}$ 계측값은 모두 환경부의 허용기준을 만족하였다. $\mathrm{CO}$ 및 $\mathrm{NO}_{\mathrm{x}}$ 배출값을 기반으로 하여 배출계수를 계산해보았다. 이렇게 계산된 산업용 목재펠릿보일러 배출계수를 저 $\mathrm{NO}_{\mathrm{x}}$ 인증버너에서 배출되는 $\mathrm{NO}_{\mathrm{x}}$ 와 비교해보았다. 분석한 결과를 요약하면 다음과 같다. 
Analysis of Emission Characteristics and Emission Factors of Carbon Monoxide and Nitrogen Oxide Emitted from Wood Pellet Combustion in Industrial Wood Pellet Boilers Supplied According to the Subsidy Program of Korea Forest Service

1. 산림청에서 지원한 산업용 목재 펠릿 보일러의 평균 용량은 $3.0 \mathrm{MW}$ 로 목재 펠릿 소비량은 약 $740 \mathrm{~kg} / \mathrm{h}$ 이다.

2. 5년간 보급된 산업용 목재펠릿보일러의 평균 $\mathrm{CO}$ 배출량은 $56 \mathrm{ppm}\left(\mathrm{OO}_{2} 12 \%\right)$ 이며, 이를 배출계수로 환산하면 0.73 $\mathrm{g} / \mathrm{kg}$ 이다.

3. 보급초기인 2012년 보급된 산업용 목재펠릿보일러에 대한 평균 CO 배출량은 $70.3 \mathrm{ppm}\left(\mathrm{OO}_{2} 12 \%\right)$ 이었으나, 보급사업 마지막 연도에 설치된 보일러의 평균 CO 배출량은 $28.9 \mathrm{ppm}$ 이다. 이는 기술개발을 통해 연소기 및 보일러 시스템을 최적화한 결과로 판단된다.

4. 5년간 보급된 산업용 목재펠릿보일러의 평균 $\mathrm{NO}_{x}$ 배출량은 $76 \mathrm{ppm}\left(\mathrm{OO}_{2} 12 \%\right)$ 이며, 이를 배출계수로 환산하면 1.63 $\mathrm{g} / \mathrm{kg}$ 이다.

5. $\mathrm{NO}_{\mathrm{x}}$ 는 시간에 따라 감소하는 경향을 나타내지 않았다. 이는 $\mathrm{NO}_{\mathrm{x}}$ 생성이 연료에 포함된 질소함량에 따라 생성되는 fuel $\mathrm{NOx}$ 가 줄어들지 않았기 때문으로 판단된다.

6. 산업용 목재펠릿보일러에서 생성되는 $\mathrm{NO}_{\mathrm{x}}$ 의 배출계수를 저 $\mathrm{NO}_{\mathrm{x}}$ 인증 $\mathrm{LNG}$ 버너 및 석탄(중유)와 비교해 보았다. 보급된 산업용 목재펠릿 보일러의 배출계수는 저 $\mathrm{NO}_{\mathrm{x}}$ 인증 $\mathrm{LNG}$ 연소보다 약 1.90 배이었으며, 탈질설비가 부착된 석탄 및 중유 보일러 에 비해 약 0.92 배이다. 